\title{
Linguistic Landscapes In Desa Kuta
}

\section{${ }^{1}$ I Wayan Mulyawan, Udayana University \\ ${ }^{2}$ Ni Ketut Ratna Erawati, Udayana University}

${ }^{1}$ Corresponding Author : moelya01@gmail.com

Received Date: 10-01-2019 Accepted Date: 28-02-2019 Published Date: 31.-07-2019

Abstract -- This research aimed to identify the presence of Linguistic Landscapes (LL) in Desa Kuta. LL is sociolinguistic study of language used in outdoor signage that firstly introduce by Landry and Bourhis (1997). Desa Kuta as one of tourist destination in Bali experiences a great development due to globalization effect. This great development can be seen clearly through the presence of outdoor signs along the main roads of Desa Kuta. The research was conducted from February to March 2019. The finding showed there are 2.549 signs along the main roads of Desa Kuta. The language used mostly in English with 1.332 signs (52\%). As for the types, there are 1.603 signs of commercial signs (65\%). In term of the function, 2.320 signs (93\%) are informative.

Keywords: linguistic landscapes, language, function.

\section{Introduction}

Language is the key interaction of human as a social being. Formerly, language is use as a means of communication between people either spoken or written. Nowdays, in this globalization era, there is one other form of communication between people and their environment. This communication is known as mass communication in form of outdoor signs. These outdoor signs may be in form of traffic signs, billboards, place names, road names, etc. This mass communications of outdoors signs is known as Linguistics Landscapes (LL). This study was firstly introduced by Landry and Bourhis (1997) as the study ole language in public space. Mulyawan (2016) stated that LL is a multilingual study of outdoor signs especially as the language of commercial signs.

The presence of outdoor signs of every place, region or territory are highly depends on the status or development of the place. So that, one place may full of outdoor signs where as other has only few out door signs. Besides, the presence of outdoor signs also indicates the characteristic of the place. 
Desa Kuta is one of tourist destination in Bali which experiences a great change in term of tourism development. In the last 4 (four) decades, Desa Kuta had transformed from Local Village into International Village.

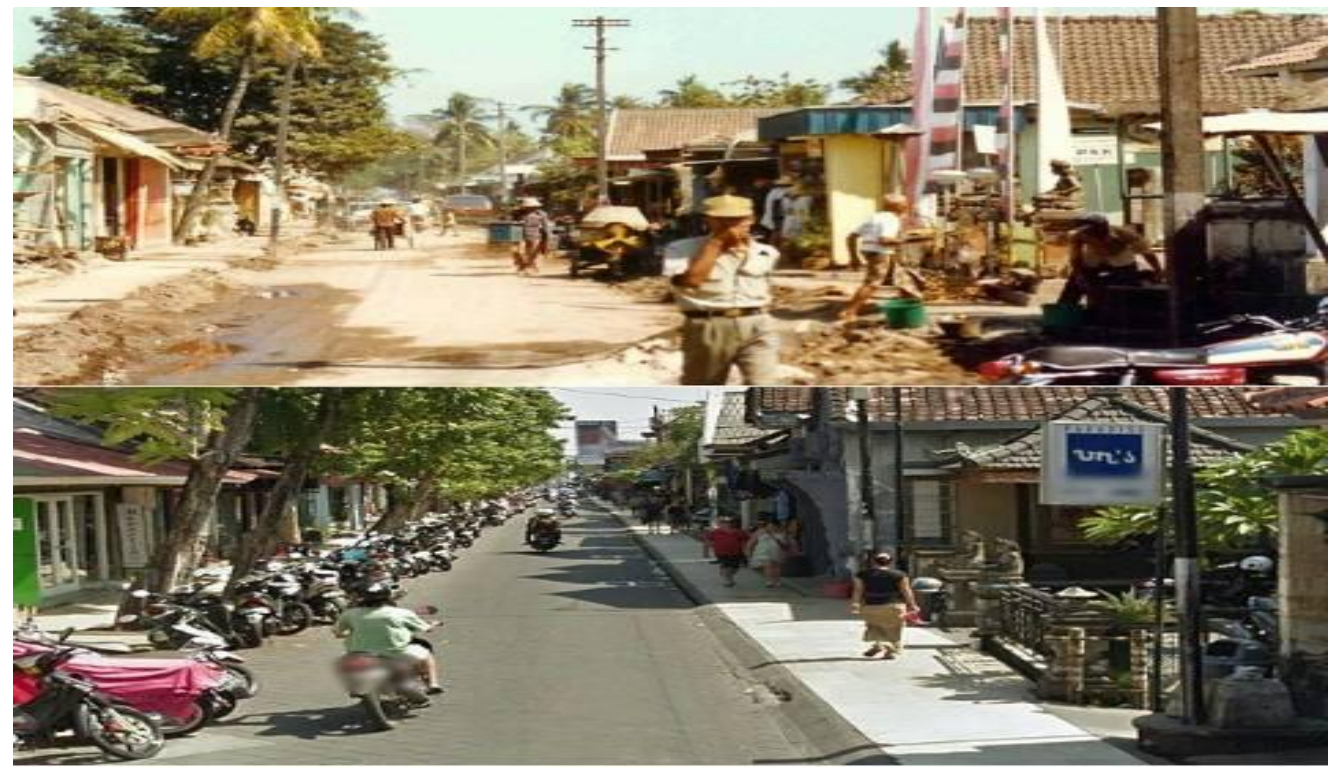

Picture 1. The Condition of Jalan Raya Kuta in 1983 (above) and present condition (below)

(Source: http://muslimbalitours.com/koleksi-foto-foto-pantai-kuta-tempo-dulu.html)

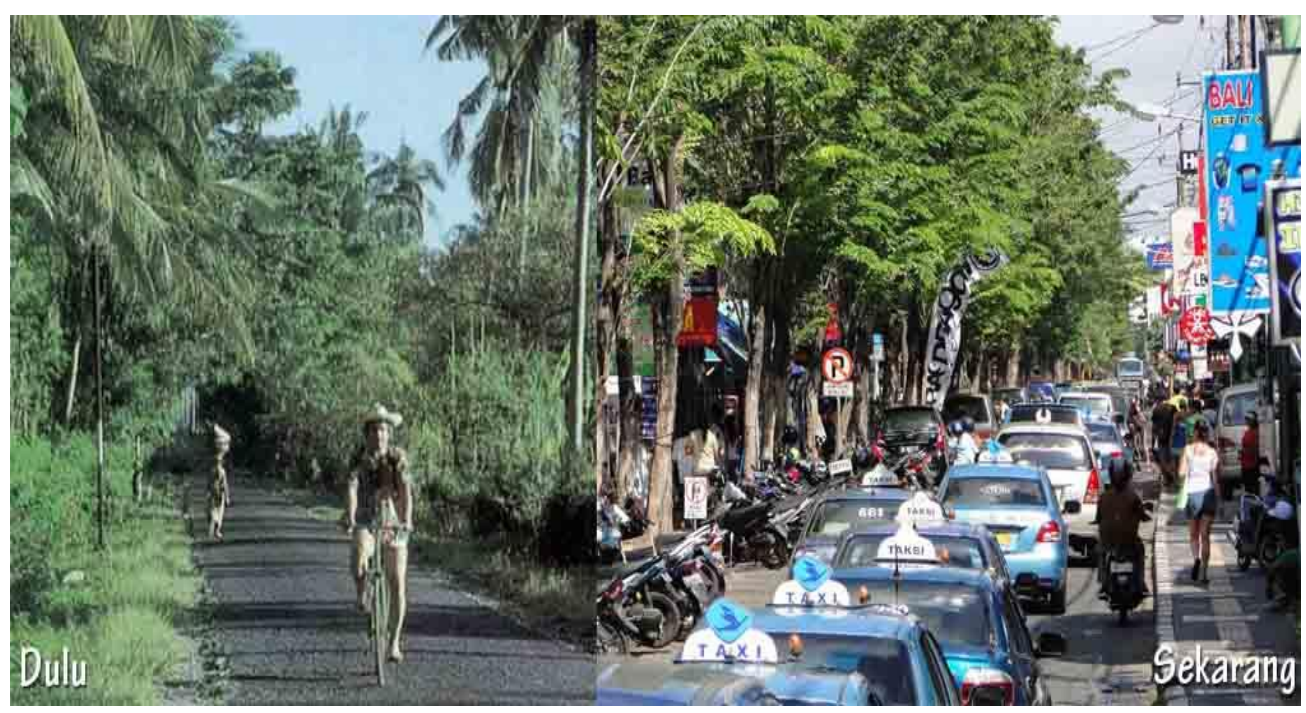

Picture 2. The Condition of Jalan Legian in 1975 (left) and present condition (right) (Source: http://inputbali.com/berita-bali/inilah-baliku-dulu-dan-baliku-kini)

Picture 1 and 2 above show the transformation Desa Kuta due to tourism development. These transformation is the continues effect of globalization which not only influence the 
material development but also give great effect to the presence of local culture and ideology. This fact is in line with Giulianotti and Robertson (2007: 2) which stated that globalization always endangered the locals.

In order to preserve the local, especially the Balinese language against effect of globalization, there for Balinese government encourages the use of Balinese language in public sphere. Majidi (2013: 37) said that the survival of local language can be seen from the use of the language as an active communication in public.

Furthermore, Mulyawan (2017b: 82) stated that the proses of emerging local culture (i.e. language) to be part of international communication in a development area known as glocalization process. One way to glocalize Balinese language is to use it as a mass media communication in public space, so that Balinese language will be read and recognized by the foreigners in Bali especially in Desa Kuta.

The fight of Balinese language and culture in public space against globalization effect, made Desa Kuta as an ideal place to conduct LL study.

\section{Research Method}

Based on its data and analysis, this research is a qualitative research, because its aims to identify the phenomena of outdoor signs in Desa Kuta as a way to preserve the local from negative effect of globalization. The data source of this research is primary data source in form of outdoor signs in surrounding Desa Kuta, such as traffic signs, billboards, place names, street names, buildings names, etc. Based on method and technic of collecting Data proposed by Kothari (2004: 7), the method used in this research is field research with participant observation, by which the process of collecting data is direct observation to Desa Kuta by the researcher himself. The technic of collecting data was photo graphic techniques by which all data were collected through documenting the outdoor signs using a digital camera. The method of analysing data was qualitative method which divided into two technic: quantification of qualitative data and subjective interpretation upon the data. 


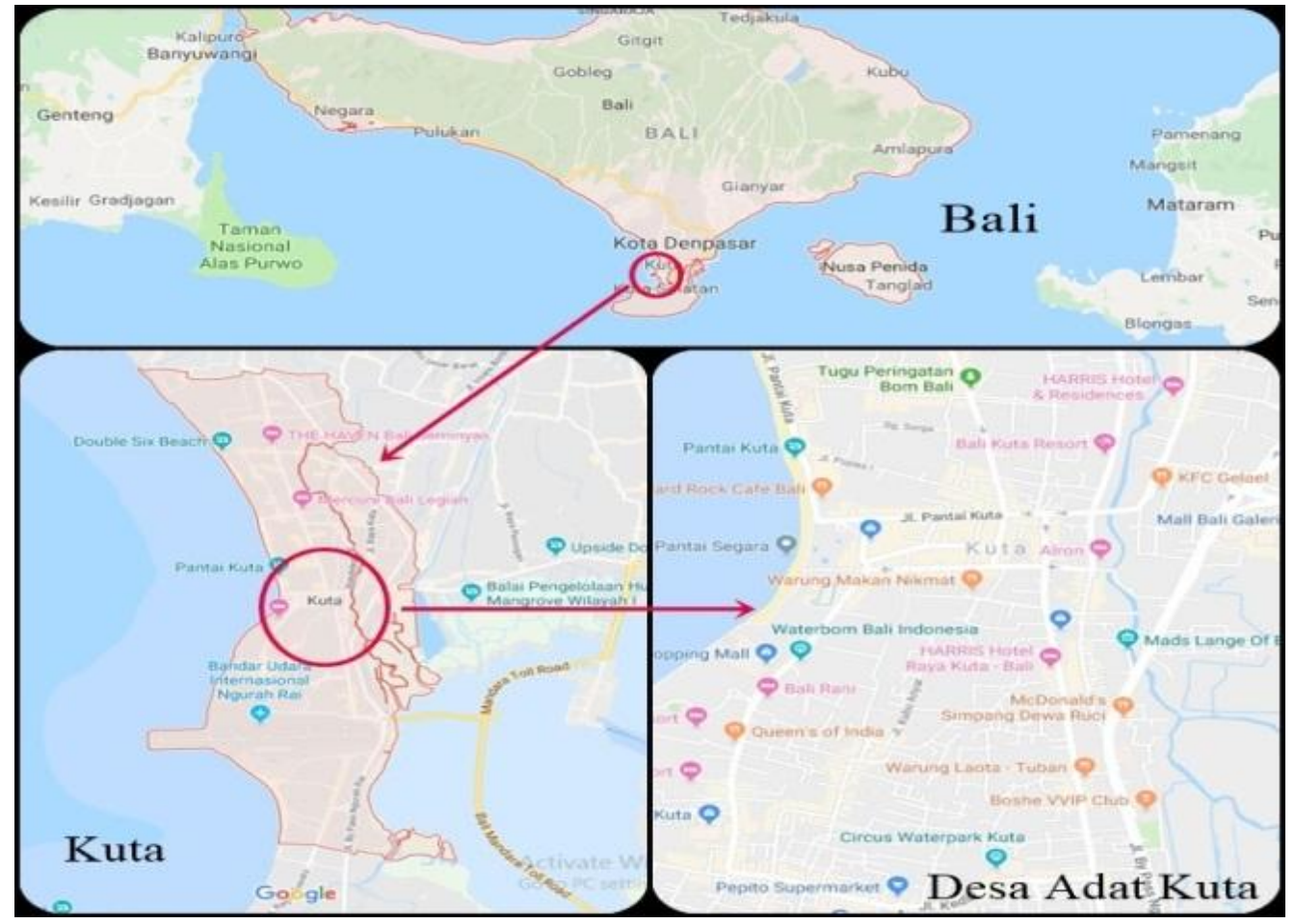

Picture 3. Desa Kuta

Source: Google map

\section{Theoretical Basis}

Linguistic Landscapes (LL) is new trend of analysis which focuses on the use of language in public space. This study was initially proposed by Landry and Bourhis (1997: 23) "Linguistic landscape refers to the visibility and salience of languages on public and commercial signs in a given territory or region". Furthermore they limit the form of LL into "... language of public road signs, advertising billboards, street names, places names, commercial shop signs, and public sign on government buildings... "(1997: 25).

Further study showed that LL is not only about the language use in public sphere but it is also involving the reflection and language status of the given territory as well as the social and cultural condition of the society (Gorter, 2006: 2; Cenoz and Gorter, 2006: 67-68; Ben-Rafael E. et al., 2006: 7; Moriarty, 2014). This approach indicates that LL is the corpus of data and the analysis will be vary depend on the interest of the researcher, in short it can be said that LL is a multidisciplinary approach. 
Mulyawan (2017a) focused his study on the use of language in commercial out door signs in Desa Kuta. His study showed that the presence of LL in Desa Kuta is the reflection of the need of Desa Kuta as a tourist destination.

\section{Result And Discussion}

Geographically Desa Kuta is located in Kuta District Badung Regency. Desa Kuta is divided into 13 administration sub area or known as Banjar (the smallest administrative sub district): Banjar Pemamoran, Banjar Pering, Banjar Pengabetan, Banjar Pelasa, Banjar Jaba Jero, Banjar Pande Mas, Banjar Temacun, Banjar Tegal, Banjar Buni, Banjar Teba Sari, Banjar Anyar, Banjar Segara and Banjar Mertha Jati.

The corpus data of this research is the outdoor signs in 6 (six) main roads of Desa Kuta: Jalan Raya Kuta, Jalan Pantai Kuta, Jalan Bakung Sari, Jalan Buni Sari, Jalan Kartika Plaza and Jalan Legian. The data were collected from February to March 2019.

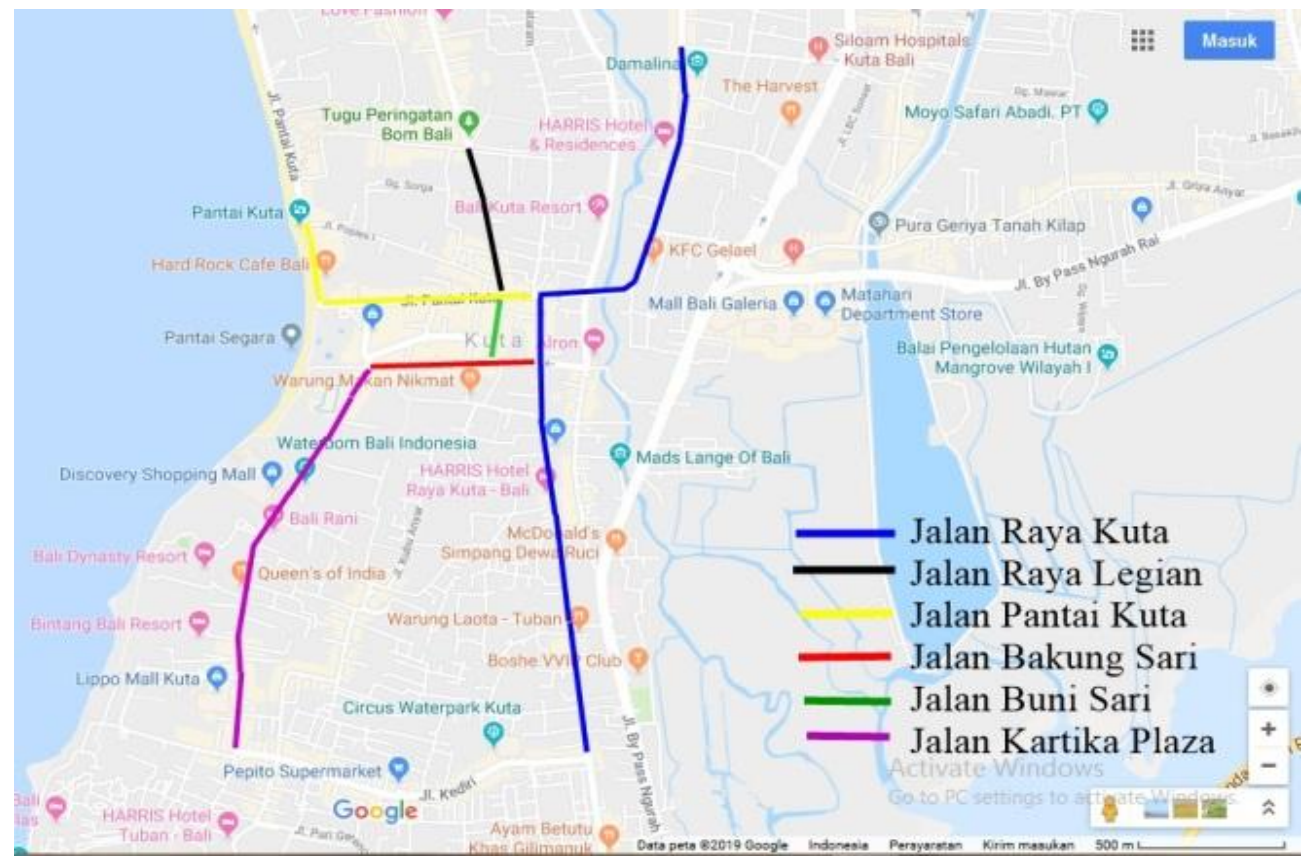

Picture 4. The Main Roads of Desa Kuta

Source: Google map. 


\begin{tabular}{rlll}
\hline No & Road & Total & \% \\
\hline 1. & Bakung Sari & 374 & 14.67 \\
2. & Buni Sari & 223 & 8.75 \\
3. & Kartika Plaza & 393 & 15.42 \\
4. & Pantai Kuta & 596 & 23.38 \\
5. & Raya Kuta & 665 & 26.09 \\
\hline 6. & Legian & 298 & 11.69 \\
& Grand Total & $\mathbf{2 5 4 9}$ & $\mathbf{1 0 0}$ \\
\hline
\end{tabular}

Table 1. The Data

The finding showed that there 2.549 outdoor signs along the 6 (six) main roads of Desa Kuta. Based on the language used, the data were grouped into 6 (six) categories:
a. Balinese language
b. Indonesian language
c. English language
d. Balinese + Indonesian
e. Combination of English and Other Language
f. Symbol, index or icon

The finding showed that only 31 out door signs (1.22\%) were in Balinese and there were 531 outdoor signs $(20.83 \%)$ in Indonesian, whereas 1.332 outdoor signs $(52.26 \%)$ were in English. These facts indicate that the use of local and national language is not represented as the host of language used in Desa Kuta. Representation of more than 50\% English indicate that the society is multilingual in order to support the status of Desa Kuta as international village

\begin{tabular}{|c|c|c|c|}
\hline No & Language & Total & $\%$ \\
\hline 1. & Balinese & 31 & 1.22 \\
\hline 2. & Indonesian & 531 & 20.83 \\
\hline 3. & English & 1332 & 52.26 \\
\hline 4. & $\begin{array}{l}\text { Balinese + } \\
\text { Indonesian }\end{array}$ & 45 & 1.77 \\
\hline 5. & $\begin{array}{l}\text { English + } \\
\text { Others }\end{array}$ & 448 & 17.58 \\
\hline \multirow[t]{2}{*}{6.} & $\begin{array}{l}\text { Symbol/ Index/ } \\
\text { Icon }\end{array}$ & 162 & 6.36 \\
\hline & Grand Total & 2549 & 100 \\
\hline
\end{tabular}

Table 2. The Language of LL 
In term of the form of the outdoor signs, the data were categories based on the form list proposed by Landry and Bourhis (1997):
a. Billboard signs
b. Government Building signs
c. Street Name signs
d. Place Name signs
e. Commercial signs
f. Traffics signs

The finding showed that commercial out door signs were the most data found with 1.603 signs (62.89). Among those 6 (six) categories proposed, there were 503 outdoor signs that were not belong to the categories dependently rather to be mixed in form, such as place name mixed with commercial signs, political advertisement, and many others micelenous form of advertisement, parking signs, local note which did not represent a place of the thing being noted in the signs. These forms of outdoor signs were categorized as mixed form.

\begin{tabular}{rlll}
\hline No & Form & Total & \% \\
\hline 1. & Billboard & 51 & 2.00 \\
2. & Government & 47 & 1.84 \\
& Building & & \\
3. & Street Name & 31 & 1.22 \\
4. & Place Name & 201 & 7.89 \\
5. & Commercial & 1603 & 62.89 \\
& Signs & & \\
6. & Traffic Signs & 113 & 4.43 \\
7. & Mixed & 503 & 19.73 \\
& Grand Total & $\mathbf{2 5 4 9}$ & $\mathbf{1 0 0}$ \\
\hline
\end{tabular}

Table 3. The Form of LL

As for the functions of the outdoor signs, the data were grouped based on the function of LL proposed by Landry and Bourhis (1997):

a. Informative Function

b. Symbolic Function 
The finding showed that most of the outdoor signs were informative with 2.320 signs (91.02\%) and 194 outdoor signs (7.61\%) were symbolic. The phenomena of mixed form also were found in functions of LL. The mixed of informative function and symbolic function were in form of the language used by which the language were mixed between Balinese language and/or Balinese Letters as a representation of the status of Balinese as the host. The total signs of mixed function were only 35 out door signs $(1.37 \%)$.

\begin{tabular}{clll}
\hline No & Function & Total & \% \\
\hline 1. & Informative & 2320 & 91.02 \\
2. & Symbolic & 194 & 7.61 \\
3. & Mixed & 35 & 1.37 \\
& Grand Total & $\mathbf{2 5 4 9}$ & $\mathbf{1 0 0}$ \\
\hline
\end{tabular}

Table 4. The Function of LL

\section{Conclusion}

Based on the discussion, it can be concluded that Desa Kuta based on the representation of the language of outdoor signs were considered to multilingual society (see table 2). As for the form and function, the theory proposed by Landry and Bourhis (1997) cannot describe all the data of outdoor signs in Desa Kuta, which led to the adding of mixed form (see table 3) and mixed functions (see table 4).

\section{Reference}

Akindele, Dele Olufemi. 2011. Linguistic Landscapes as Public Communication: A Study of Public Signage in Gabarone Botswana. International Journal of Linguistics 2011, Vol. 3, No. 1: E39. Macrothink Institute.

Bally, Charles and Sechehaye, Albert. (Eds) 1915. Course in General Linguistics Ferdinand de Saussure. McGrow Hill: London.

Ben-Rafael E. et al. 2006. Linguistic Landscape as Symbolic Construction of the Public Space: The Case of Israel. In Durk Gorter (Eds). Linguistic Landscape: A New Approach to Multilingualism. pp. 7-30.Clevedon: Multi Lingual Matters Ltd.

Cheng, Y.C. 2000. A CMI-Triplization Paradigm for Reforming Education in the New Millennium. International Journal of Educational Management. 14(4), 156-174. 
Giulianotti, R. and Robertson, R. Forms of glocal-ization: globalization and the migration strategies of Scottish football fans in North America. Journal Sociology, 41 (1), pp. 133-152. SAGE Publication.

Gorter, Durk. 2006. Further Possibilities for Linguistic Landscape Research. Clevedon: In Durk Gorter (Eds). Linguistic Landscape: A New Approach to Multilingualism. pp. 81-89. Clevedon: Multi Lingual Matters Ltd.

Huebner, Thom. 2006. Bangkok's Linguistic Landscapes: Environmental Print, Code mixing and Language Change. In Durk Gorter (Eds). Linguistic Landscape: A New Approach to Multilingualism. pp. 31-51. Clevedon: Multi Lingual Matters Ltd.

Kothari, C.R. 2004. Research Methodology: Methods and Techniques. New Age International (P) Limited, Publishers

Landry, Rodrigue and Bourhis, Richard Y. 1997. Linguistic Landscape and Ethnolinguistic Vitality: An Empirical Study. Journal of Language and Social Psychology 16, 23-49.

Mulyawan, I. W. 2017b. Glocalization of Balinese language as outdoor signs in Desa Adat Kuta Bali. International Journal of Education, Agustus 2017, Vol. 10, No. 1. Universitas Pendidikan Indonesia.

Mulyawan, IW. 2010. Hipersemiotika Periklanan (Analisa Praktis). Denpasar: Udayana University Press.

Mulyawan, IW. 2016. Structural Analysis of IFAW.org Advertisement. Jurnal Ilmiah AURORA, pp 178-187. Universitas Kristen Maranatha.

Mulyawan, IW. 2017a. Linguistics Landscapes: Commercial Outdoor Sign in Kuta Bali. International Journal of Linguistics, April 2017, Vol. 9, No. 2. pp. 1-9 (doi:10.5296/ijl.v9i1.10761). Macrothink Institute.

\section{Acknowledgement}

I would like to express my sincere gratitude to my first supervisor Prof. Dr. Ketut Artawa, M.A, Dr. Made Sri Satyawati, M.Hum. as my second supervisor and Dr. Ni Ketut Ratna Erawati, M.Hum. as my third supervisor for their patience and profesional guidence during the completion of this study. 


\section{1st AUthors ProfiLe}

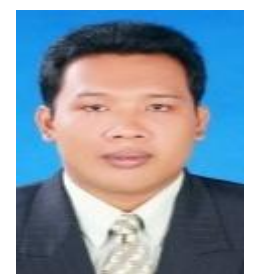

I Wayan Mulyawan was born in Badung Bali Indonesia on December 1st 1978. He was graduated from Udayana University for both undergraduate and post graduate degree. At the moment, he is a Ph.D. candidate in Udayana University. He works as a LECTURER in English Department Faculty of Arts, Udayana University since 2006. He is now the Chair Person of the Faculty Business Centre (FBC). Previously, he was the head of English Non Regular Program. I Wayan Mulyawan, S.S., M.Hum have published a book of Discourse Advertising and many International/Regional article. In the last three years the focus of his publication is the study of Linguistic Landscapes, one of the publication is entitle Impact of tourism on vernacular outdoor signs in Ubud, Bali, Indonesia was published in ISVS e-journal which indexed in Scopus. 